\title{
Role of Tamm-Horsfall protein in the binding and in vivo phagocytosis of type 1 fimbriated Escherichia coli by mouse peritoneal macrophages
}

\section{A.C.S.C. Bastos ${ }^{1}$, L.B. Santos ${ }^{1}$, W.M.S.C. Tamashiro ${ }^{1}$ A.T. Yamada², U.M. O liveira ${ }^{3}$ and T. Yano ${ }^{1}$}

\author{
Departamentos de ${ }^{1} \mathrm{M}$ icrobiologia e Imunologia and \\ ${ }^{2} \mathrm{H}$ istologia e Embriologia, Instituto de Biologia, and \\ 3Patologia Clínica, Faculdade de Medicina, \\ Universidade Estadual de Campinas, Campinas, SP, Brasil
}

\begin{abstract}
\section{Correspondence}

T. Yano

Departamento de Microbiologia e

Imunologia, IB, Unicamp

13083-970 Campinas, SP

Brasil

Fax: + 55-19-3788-8190

E-mail: tyano@ obelix.com.br

Tamm-Horsfall glycoprotein (THP) contains manno-oligosaccharides that are recognized by type 1 fimbriae (F1) of Escherichia coli. In the present study, we examined the in vivo phagocytic activity of mouse peritoneal macrophages after treatment of bacteria with THP. At low THP concentrations $(12.5 \mu \mathrm{g} / \mathrm{ml}$ and $50 \mu \mathrm{g} / \mathrm{ml})$ no significant difference was observed in the phagocytosis of E. coli $\mathrm{F} 1^{+}$. However, at high THP concentrations $(500 \mu \mathrm{g} / \mathrm{ml}$ and $1250 \mu \mathrm{g} / \mathrm{ml})$ we obtained a reduction of bacterial phagocytosis by mouse peritoneal macrophages.
\end{abstract}

Research supported by FAPESP

Received May 30, 2000

Accepted April 10, 2001

\section{Key words}

- Tamm-Horsfall protein

- Type 1 fimbriated E. coli

- Phagocytosis

\section{Introduction}

Several members of the Enterobacteriaceae family, including some strains of Escherichia coli, have numerous filamentous fimbrial structures on their surface (1). Some strains of type 1 fimbriated E. coli adhere to uroepithelial cells and may cause lower urinary tract infections (cystitis) (2), but their relationship with upper urinary tract infections (pyelonephritis) is still not clear. These fimbriae facilitate the attachment of bacteria to mannose-containing receptors on a variety of host cells, as well as to a urinary tract glycoprotein known as Tamm-Horsfall protein (THP) (3-5).

Tamm-Horsfall glycoprotein, which is synthesized exclusively by the kidney (6), is present in large quantities $(20-200 \mathrm{mg} / \mathrm{ml})$ in human urine and has been implicated in a variety of renal diseases, although its physiological role is unknown (7). The attachment of type 1 fimbriated $E$. coli to THP suggests a protective role of THP in the defense against urinary tract colonization and infection by this strain of E. coli $(3,5)$. On the other hand, an in vitro study (8) demonstrated that bacteria coated with THP are less susceptible to phagocytosis by polymorphonuclear leukocytes (PMNL), and this may allow the infection to persist. Type 1 fimbriae can also bind to mannose-containing receptors on the membranes of PMNL and mouse peritoneal macrophages (9).

The aim of the present study was to examine in an in vivo assay the effect of THP concentration on bacterial phagocytosis by mouse peritoneal cavity macrophages, a phenomenon that has only been described in vitro by others. 


\section{Material and Methods}

\section{Bacterial strains}

E. coli strain ORN115, a recombinant with type 1 fimbriae (10), was obtained from Dr. Paul E. Orndorff (Department of Microbiology, Pathology, and Parasitology, North Carolina State University, Raleigh, NC, USA). Strains of non-fimbriated E. coli (K12 C600) were also used. The bacteria were cultured statically in trypticase soy broth for $18 \mathrm{~h}$ at $37^{\circ} \mathrm{C}(11)$. The presence of type 1 fimbriae was confirmed by serum agglutination on glass slides with specific antiserum against $\mathrm{F}^{+}$and by agglutination of guinea pig erythrocytes on slides.

\section{Purification of THP}

THP from human urine was purified by salt precipitation (12). After dialysis against deionized water and lyophilization, the material was dissolved in $8 \mathrm{M}$ urea and chromatographed on a Sepharose CL-6B column $(2 \mathrm{~cm} \times 58.6 \mathrm{~cm})$ equilibrated with $30 \mathrm{mM}$ phosphate buffer, $\mathrm{pH} 6.8$, containing $2 \mathrm{M}$ urea at a flow rate of $2 \mathrm{ml} / \mathrm{min}$. The elution profile was monitored at $280 \mathrm{~nm}$. The active peak appeared as a single band (molecular weight 294,000 ) on SDS-PAGE (13) after staining with silver nitrate (14). This band was positively identified as THP by Western blotting (15) following incubation with an anti-THP monoclonal antibody (Accurate Chemical and Scientific, Westbury, NY, USA). Protein concentrations during purification were determined using a Bio-Rad protein assay kit (Bio-Rad Laboratories, Hercules, CA, USA).

\section{Preparation of anti-THP serum}

Polyclonal anti-THP antiserum was produced in New Zealand rabbits as described by Dawnay et al. (16), with some modifications. The rabbits were immunized subcuta- neously at various sites with $250 \mu \mathrm{g}$ of THP in Freund's complete adjuvant. After 30 and 60 days, the animals received an additional injection of $100 \mu \mathrm{g}$ of THP in Freund's incomplete adjuvant and were bled 10 days after the final dose.

\section{Binding of E. coli to immobilized THP}

The methodology developed by Karlsson et al. (17) was used. After SDS-PAGE (13), THP was transferred to a nitrocellulose membrane (15) and blocked by incubation with $5 \%$ non-fat dry milk in $20 \mathrm{mM}$ PBS, $\mathrm{pH} 7.4$, at room temperature for $1 \mathrm{~h}$. The membrane was then washed twice in $20 \mathrm{mM}$ PBSTween buffer, $\mathrm{pH} 7.4$, and incubated in a vertical position in $10 \mathrm{ml}$ of a bacterial suspension $\left(10^{8}\right.$ cells $\left./ \mathrm{ml}\right)$ of $E$. coli ORN115 and $E$. coli $\mathrm{K} 12 \mathrm{C} 600$ for $1 \mathrm{~h}$ at room temperature with no shaking. A control sample containing $20 \mathrm{mg} / \mathrm{ml} \mathrm{D-mannose} \mathrm{was} \mathrm{also}$ run. After this period, the membranes were washed in $20 \mathrm{mM}$ PBS-Tween buffer and placed protein side up on eosin blue methylene (EMB) agar plates and incubated at $37^{\circ} \mathrm{C}$ for $18 \mathrm{~h}$ to allow colony formation.

\section{Phagocytosis assay}

Two hundred microliters of $E$. coli ORN1 15 suspension $\left(10^{8}\right.$ cells $/ \mathrm{ml}$ in $20 \mathrm{mM}$ PBS, pH 7.4) was centrifuged at $17,700 \mathrm{~g}$ and resuspended in $20 \mathrm{mM}$ PBS, pH 7.4, containing THP $(2.5,25,100$ and $250 \mu \mathrm{g} / 0.2$ $\mathrm{ml}(8)$ ) and incubated for $30 \mathrm{~min}$ at $37^{\circ} \mathrm{C}$.

The peritoneal cavities of 40 female 810-week-old BALB/c mice supplied by the University's central animal house (CEMIB/ Unicamp) were stimulated by injecting a $10 \%$ peptone solution (18) (Difco Laboratories, Detroit, MI, USA) ( $0.5 \mathrm{ml} /$ animal). Three days later, a control group of eight mice were injected intraperitoneally (ip) with $0.2 \mathrm{ml}$ of E. coli $\left(10^{8}\right.$ cells $/ \mathrm{ml}$ in $20 \mathrm{mM}$ PBS, pH 7.4 (19)) and four other groups received a 0.2$\mathrm{ml}$ suspension of E. coli $\left(10^{8}\right.$ cells $\left./ \mathrm{ml}\right)$ con- 
taining $2.5,25,100$ and $250 \mu \mathrm{g}$ of THP/0.2 $\mathrm{ml}$, respectively. Thirty minutes after the ip injections (18), the mice were sacrificed by cervical dislocation, and their peritoneal cavities were washed with $3 \mathrm{ml}$ of $20 \mathrm{mM}$ PBS containing 5 IU heparin $/ \mathrm{ml}$. The macrophages collected were resuspended to $2 \times 10^{6}$ cells/ $\mathrm{ml}$ in $20 \mathrm{mM}$ PBS, $\mathrm{pH}$ 7.4. This suspension was cytocentrifuged and the cells were stained with Giemsa (8). The percentage of phagocytes was determined by counting phagocytic and non-phagocytic cells in a total of 100 cells. The numbers of macrophages were counted by light microscopy at a magnification of 100X. Differences between the experimental and control groups were compared by the Duncan multiple range test using a statistical software package (SAS Institute, 1986) (20).

\section{Results}

\section{Characterization of THP}

Chromatography of THP on Sepharose CL-6B in $8 \mathrm{M}$ urea produced two main peaks, the first of which contained THP (data not shown). After applying SDS-PAGE and staining with silver nitrate (Figure 1), THP was detected as a single band of $94 \mathrm{kDa}$. Identical results were obtained by Western blotting (Figure 2).

\section{Binding of E. coli to immobilized THP}

Type 1 fimbriated E. coli bound to immobilized THP on nitrocellulose membranes (data not shown). This binding was observed after multiplication of $E$. coli around the $94-\mathrm{kDa}$ THP band on EMB agar plates. No growth was observed in the presence of D-mannose (20 $\mathrm{mg} / \mathrm{ml}$ ) or with E. coli $\mathrm{K} 12 \mathrm{C} 600$.

\section{Phagocytosis}

Duncan's multiple comparisons test revealed significant differences $(\mathrm{P}<0.0001)$ in

the phagocytosis of bacteria associated with THP. When the bacteria were preincubated with THP $(2.5 \mu \mathrm{g}$ or $10 \mu \mathrm{g} / 0.2 \mathrm{ml})$ there were no significant differences in phagocytosis compared to bacterial suspensions without

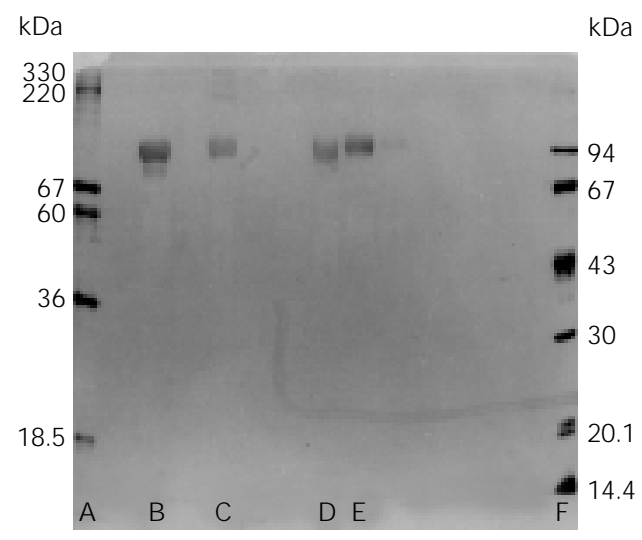

Figure 1. SDS-PAGE of purified Tamm-Horsfall protein (THP). Proteins were loaded onto $10 \%$ polyacrylamide gels in the presence of $\alpha$-mercaptoethanol and stained with silver nitrate. Lane A, Molecular mass standards of thyroglobulin $(330 \mathrm{kDa})$, ferritinhalf unit (220 kDa), bovine albu$\min (67 \mathrm{kDa})$, catalase $(60 \mathrm{kDa})$ lactate dehydrogenase (36 kDa), and ferritin (18.5 kDa); lanes B$D$, THP purified by gel filtration chromatography on a Sepharose CL-6B column; lane E, standard THP; lane $F$, molecular mass standards of phosphorylase B (94 kDa), bovine albumin (67 kDa), ovalbumin (43 kDa), carbonic anhydrase (30 kDa), trypsin (20.1 kDa), and $\alpha$-lactalbumin (14.4 kDa).

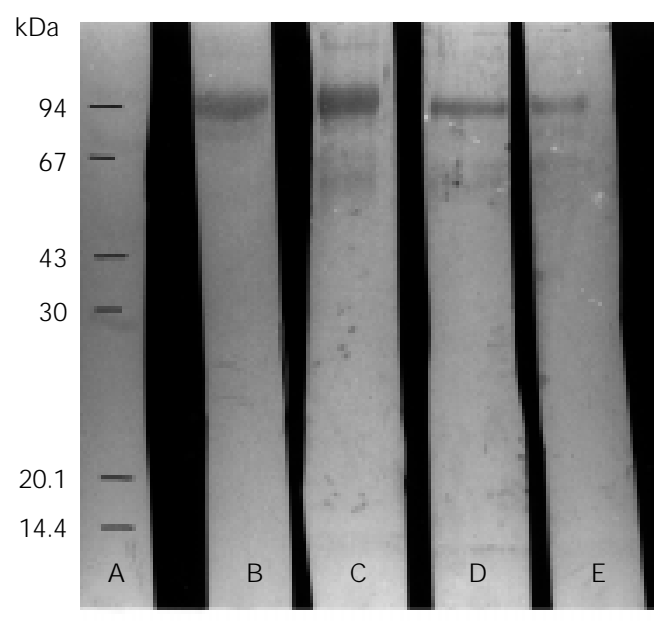

Table 1. Percentage of E. coli F1+ phagocytosis by mouse peritoneal macrophages after incubation of bacteria with Tamm-Horsfall protein (THP).

\begin{tabular}{cc}
\hline THP $(\mu \mathrm{g} / 0.2 \mathrm{ml})$ & Phagocytosis $(\%)$ \\
\hline 0 & 97.8 \\
2.5 & 97.0 \\
10 & 96.7 \\
100 & 86.8 \\
250 & 82.2 \\
\hline
\end{tabular}

Differences between the experimental and control groups were compared by the Duncan multiple range test using a statistical software package (Ref. 20) $(P=0.0001 ; F=33.82)$.
Figure 2. Western blotting of purified Tamm-Horsfall protein (THP). Lane A, Molecular mass standards (Pharmacia). Lanes B and C, THP purified by gel filtration and detected with mouse monoclonal anti-THP (Accurate Chemical and Scientific) and rabbit antiserum, respectively. Lane D, Standard THP detected with mouse monoclonal anti-THP, and lane E, standard THP detected with rabbit polyclonal anti-THP. 
THP (Table 1). However, when the concentration of THP was increased to $100 \mu \mathrm{g}$ and $250 \mu \mathrm{g} / 0.2 \mathrm{ml}$ phagocytosis was significantly decreased.

\section{Discussion}

The ability of bacteria to bind to epithelial surfaces through fimbriae is correlated with their pathogenicity (1). Some strains of $E$. coli isolated from patients with lower urinary tract infections express type 1 fimbriae (2). These structures allow the bacteria to adhere to receptors containing mannose on the surface of host epithelial cells (3) and phagocytes (19). Glycoproteins present in urine can function as receptors for type 1 fimbriae and influence bacterial adhesion to the uroepithelium and to phagocytes $(6,8)$.

As shown here, the urinary glycoprotein THP, which contains the sugar D-mannose, functions as a mannose-sensitive receptor for type 1 fimbriated E. coli. These results agree with the studies of Orskov (3) who suggested this binding to be mannose-sensitive. We observed this interaction at low THP concentrations $(5 \mu \mathrm{g} / \mathrm{ml})$, although others (21) have reported this effect only at THP concentrations up to $100 \mu \mathrm{g} / \mathrm{ml}$. These same investigators observed that the receptor for $\mathrm{F}^{+}$in urine was a low molecular weight substance. This contrasts with our results and previous reports (22) which characterized THP as a high molecular weight $(94,000)$ glycoprotein.

THP may act as a competitive inhibitor of the binding of $E$. coli $\mathrm{F}^{+}$to PMNL (8). PMNL are important cells in the initial stages of infection, before the formation of specific antibodies when serum opsonin levels are low.

We used mouse peritoneal macrophages to assess the effects of THP on the phagocytosis of $E$. coli $\mathrm{F}^{+}$. The phagocytosis of $E$. coli $\mathrm{F}^{+}$varied with THP concentration. When E. coli $\mathrm{F}^{+}$was preincubated with high THP concentrations (100 $\mu \mathrm{g}$ or $250 \mu \mathrm{g} /$ $0.2 \mathrm{ml}$ ) the phagocytosis of bacteria by mac- rophages decreased. In contrast, when $E$. coli $\mathrm{F}^{+}$was preincubated with lower THP concentrations $(2.5 \mu \mathrm{g}$ and $10 \mu \mathrm{g} / 0.2 \mathrm{ml})$ there was no significant effect on phagocytosis.

Horton et al. (23) suggested that THP may stimulate phagocytosis since in aggregated form and at high concentrations $(>500$ $\mu \mathrm{g} \mathrm{THP} / \mathrm{ml}$ ) it increased neutrophil phagocytosis and lysosome degranulation. However, these high concentrations exceed the physiological levels of THP in urine (20-200 $\mu \mathrm{g} / \mathrm{ml}$ ) and contradict results obtained by Reinhart et al. (24), who observed a decrease in the respiratory burst of PMNL after the ingestion of $E$. coli $\mathrm{F}^{+}$bound to THP.

Our data agree with the results of Kuriyama and Silverblatt (8), who observed a decrease in bacterial phagocytosis by PMNL, even at THP concentrations $<2.5 \mu \mathrm{g} / \mathrm{ml}$. Nevertheless, THP did not totally inhibit bacterial binding and phagocytosis by macrophages. Multiple mannose-sensitive binding sites between $\mathrm{F}^{+}$and THP have been suggested to contribute to bacterial binding (8). This could explain why THP only partially blocked the phagocytosis of E. coli $\mathrm{F}^{+}$ by mouse peritoneal macrophages since this glycoprotein may act as a competitive inhibitor of $E$. coli $\mathrm{F}^{+}$binding to macrophage surface receptors.

These results confirm other reports (24) showing that THP inhibits binding between type 1 fimbriated E. coli $\mathrm{F}^{+}$and $\mathrm{PMN}$. Kuriyama and Silverblatt (8) also observed that type 1 fimbriated E. coli, which are usually efficiently phagocytosed by PMN, no longer become associated with these cells if they are coated with THP. This antiopsonic effect is similar to that observed when group A streptococci bind fibrinogen to their surface M protein (25).

The occurrence of THP on bladder or kidney mucosa suggests a mechanism similar to the interaction of mucus with tracheal and intestinal epithelium (26). There is still no conclusive evidence that THP occurs in 
transitional epithelium in vivo.

Our results support the view that the soluble THP found in urine contains receptors which are recognized by type 1 fimbriae, thereby enhancing the urinary elimination of $E$. coli. However, in certain pathological states, this glycoprotein may accumulate on the renal parenchyma or perirenal tissue (27), and act as a binding site for E. coli $\mathrm{F}^{+}$, allowing bacterial colonization and possibly decreasing phagocytosis by macrophages.

\section{Acknowledgments}

We would like to thank Dr. Arício X. Linhares (IB, Unicamp) for performing the statistical analyses, Erivaldo José da Silva for technical assistance, and Linda Gentry El-Dash for revising the manuscript.

\section{References}

1. Duguid J P, Clegg S \& Wilson MI (1979). The fimbrial and nonfimbrial haemagglutinins of Escherichia coli. J ournal of Medical Biology, 6: 697-701.

2. Reid G \& Sobel J P (1987). Bacterial adherence in the pathogenesis of urinary tract infection: a review. Infectious Disease Reviews, 9: 470-487.

3. Orskov I, Ferencz A \& Orskov F (1980). Tamm-Horsfall protein or uromucoid is the normal urinary slime that traps type 1 fimbriated Escherichia coli. Lancet, 1: 887 (Abstract).

4. Orskov I, Orskov F \& Birch-Andersen A (1980). Comparison of Escherichia coli fimbrial antigen $\mathrm{F} 7$ with type 1 fimbriae. Infection and Immunity, 27: 657-666.

5. Wu AM, Wu JH \& Pak J (1998). TammHorsfall protein (THP) inhibits the binding of type 1-fimbriated E. coli to uroplakins IA and IB: role of THP in urinary tract defense. J ournal of Urology, 159 (Suppl): 310 (Abstract).

6. Bachmann S, Metzger R \& Bunnemann B (1990). Tamm-Horsfall protein-mRNA synthesis is localized to the thick ascending limb of Henle's loop in rat kidney. Histochemistry, 94: 517-523.

7. Kumar S \& Muchmore A (1990). TammHorsfall-protein-uromodulin (1950-1990). Kidney International, 37: 1395-1401.

8. Kuriyama SM \& Silverblatt FJ (1986). Effect of Tamm-Horsfall urinary glycoprotein on phagocytosis and killing of type-1 fimbriated Escherichia coli. Infection and Immunity, 51: 193-198.

9. Bar-Shavit Z, Ofek I, Goldman R, Mirelman D \& Sharon N (1977). Mannose residues on phagocytes as receptors for the attachment of Escherichia coli and Salmonella typhi. Biochemical and Biophysical Research Communications, 78: 455-460.

10. Orndorff PE, Spears PA, Schaver D \& Falkow $S$ (1985). Two models of control of pil $A$, the gene enconding type 1 pilin in Escherichia coli. J ournal of Bacteriology, 164: 321-330.

11. Blumenstock B \& J ann K (1982). Adhesion of piliated Escherichia coli strains to phagocytes: difference between mannose-sensitive pili and those with mannose-resistant pili. Infection and Immunity, 35: 264-269.

12. Tamm I \& Horsfall FL (1950). Characterisation and separation of an inhibitor of viral hemagglutination present in urine. Proceedings of the Society for Experimental Biology and Medicine, 74: 108-114.

13. Laemmli UK (1970). Cleavage of structural protein during the assembly of the head of bacteriophage T4. Nature, 227: 680-685.

14. Wray W, Boulikas T, Wray VP \& Hancock $R$ (1981). Silver staining of proteins in polyacrylamide gels. Analytical Biochemistry, 118: 197-203.

15. Burnette WN (1981). "Western blotting": Electrophoretic transfer of protein from sodium dodecyl sulfate-polyacrylamide gels to unmodified nitrocellulose and radiographic detection with antibody and radioiodinated protein A. Analytical Biochemistry, 112: 195-203.

16. Dawnay A, M CLean C \& Cattel WR (1980). The development of a radioimmunoassay for Tamm-Horsfall glycoprotein in serum. Biochemical J ournal, 185: 679-687.

17. Karlsson A, Mackjäll $M$, Strömberg $N$ \& Dahlgren C (1995). Detection of glycoprotein receptors on blotting membranes by binding of live bacteria and amplification by growth. Analytical Biochemistry, 224: 390-394.

18. Buchmeier NA \& Heffron F (1989). Intracellular survival of wild-type Salmonella typhimurium and macrophage-sensitive mutants in diverse populations of macrophages. Infection and Immunity, 57: 1-7.
19. Thomas DBL, Davies M, Peters J R \& Williams J D (1993). Tamm-Horsfall protein binds to a single class of carbohydrate specific receptors on human neutrophils. Kidney International, 44: 423-429.

20. SAS Institute Inc. (1986). SAS User's Guide: Statistics. Version 6. Cary, North Carolina.

21. Parkkinen J, Virkola R \& Korhonen TK (1988). Identification of factors in human urine that inhibit the binding of Escherichia coli adhesins. Infection and Immunity, 56: 2623-2630.

22. J ohnstone $L M$, J ones $C L$, Walker RG \& Powell HR (1994). Tamm-Horsfall protein: are serum levels a marker for urinary tract obstruction? Pediatric Nephrology, 8: 689693.

23. Horton J K, Davies M, Topley N, Thomas D \& Williams J D (1990). Activation of the inflammatory response of neutrophils by Tamm-Horsfall glycoprotein. Kidney International, 37: 717-726.

24. Reinhart $\mathrm{H}$, Obedeanu N, Merzbach $\mathrm{D} \&$ Sobel J D (1991). Effect of Tamm-Horsfall protein on chemoluminescence response of polymorphonuclear leukocytes to uropathogenic Escherichia coli. J ournal of Infectious Diseases, 164: 404-406.

25. Whitnack E \& Beachey EH (1982). Antiopsonic activity of fibrinogen bound to $M$ protein on the surface of group A streptococci. J ournal of Clinical Investigation, 69: 1042-1045.

26. Fowler J rJ E, Mariano M \& Lau J LT (1987). Interaction of urinary Tamm-Horsfall protein with transitional cells and transitional epithelium. J ournal of Urology, 138: 446448.

27. Truong LD, Ostrowski ML \& Wheeler TM (1994). Tamm-Horsfall protein in bladder tissue: morphologic spectrum and clinical significance. American J ournal of Surgical Pathology, 18: 615-622. 